\title{
Visual Media in Team Accelerated Instruction to Improve Mathematical Problem-Solving Skill
}

\author{
Sri Adi Widodo ${ }^{1}$, Muhammad $\operatorname{Irfan}^{1}$, Leonard $^{2}$, Harina Fitriyani ${ }^{3}$, Krisna Satrio Perbowo ${ }^{4}$, \\ Trisniawati $^{1}$ \\ \{ sriadi@ustjogja.ac.id, muhammad.irfan@ustjogja.ac.id, leonard@unindra.ac.id, \\ harina.fitriyani@pmat.uad.ac.id, krisna_satrio@uhamka.ac.id, trisniawati@ustjogja.ac.id\}
}

\author{
Universitas Sarjanawiyata Tamansiswa, Yogyakarta, Indonesia ${ }^{1}$ \\ Universitas Indraprasta PGRI, Jakarta, Indonesia ${ }^{2}$ \\ Universitas Ahmad Dahlan, Yogyakarta, Indonesia ${ }^{3}$ \\ Universitas Muhammadiyah Prof Hamka, Jakarta, Indonesia ${ }^{4}$
}

\begin{abstract}
The ability to solve mathematical problems is one of the abilities that must be possessed by every student. To improve this ability, a learning model is needed that can construct knowledge for each student, one of the alternative constructivist learning including Team Accelerated Instruction. In Mathematics learning, one of the obstacles that is often experienced by teachers and students include the concept of mathematics that is abstract, so that students have difficulty understanding the concept. To bridge the mathematical concept that is an abstraction, a media is needed that can concretize the abstract mathematical concepts. This article aims to construct Team Accelerated instruction using visual media to improve mathematical problem solving skills. The results of the instruction can be concluded that by using visual media on Team Accelerated Instruction learning, the skills of mathematical problem solving is thought to be more.
\end{abstract}

Keywords: Visual Media, Team Accelerated Instruction, Mathematical Problem-Solving

\section{Introduction}

The purpose of learning mathematics for behaviorism is to memorize material so that students will be given material and practice questions repeatedly [1]. By being given material and repeated practice questions students are considered to master the mathematical material if they are able to remember and apply the rules, steps, and examples that have been conveyed by the teacher. In other words, behaviorism learning is more concerned with learning outcomes compared to the learning process. As a result students consider mathematics as a collection of facts that can be separated from each other and can be memorized. Whereas if it refers to the mathematical, axiomatic, abstract, deductive, and symbolic nature, the process of memorizing a collection of facts in mathematics is deemed inappropriate. This is because mathematics is not a collection of facts that must be memorized but a collection of facts that must be understood by the concept [2], although it cannot be denied that there are still teachers who regard students 
as passive objects by giving memorized material concepts [3], giving Math material and practice questions repeatedly so students can master mathematical concepts. As a result students consider mathematics [4] frightening, always competing to get the best end result without seeing the process of finding concepts or facts in mathematics.

Basically, the main task of a math teacher is to help students get information, ideas, skills, values, and ways of thinking and ways of expressing opinions. So learning is an active process where students build new knowledge based on the experience they already have. In the view of constructivism, knowledge must be built by students themselves, knowledge cannot be transferred from teacher to student, students are actively involved in constructing knowledge continuously and the teacher acts as a facilitator by providing means and situations so that the construction process of students' knowledge goes smoothly. Constructivist belief believes that learning is not merely transferring knowledge that is outside of itself, but more about how the brain processes and interprets new experiences with the experiences that exist in itself.

Constructivists state that knowledge is not just a collection of facts as considered by behaviorism, but knowledge is the human mind with all the ideas and concepts that are found freely. The concept does not only follow simple inductive observations but can also go through a deductive process even through an imaginative process. In line with this thought, students must be actively involved in learning mathematics so that mathematics can be meaningful and new information must be linked to the students' prior knowledge so that information can be integrated into the schemes that are already owned by students. Although in cognitive constructivism knowledge is learned from individual students to build their own knowledge from their experiences while social constructivism of knowledge is built and obtained from social interaction processes[5], but both in cognitive constructivism and social constructivism, knowledge will be composed or builds up in students' minds when students try to organize new experiences based on schemes already in the minds of students $[4,6]$.

In order for knowledge to be constructed, the mathematics teacher is expected to provide new experiences by linking the knowledge already possessed by students, providing alternative learning experiences, integrating learning so that social interactions occur, utilizing the media to make learning more interesting, and involving students both socially and emotionally so that mathematics becomes more interesting $[5,7]$. This is in contrast to behaviorism who emphasize providing stimulus repeatedly so that students can respond regularly when given the same stimulus. Constructivists believe that knowledge cannot be transferred from one's mind to the minds of others. Instead the student himself must construct knowledge by interacting with others. This is because the constructivism considers that knowledge is a social process of construction that is connected by language and social processes of construction. So the mathematics teacher needs to express mathematics into everyday life and instead interpret daily life into mathematical material.

Cooperative learning is a learning model the impact of constructivism, where knowledge will be constructed if students find and understand the concept in discussion and work together in mastering the material given by the teacher, knowledge is constructed if students find and understand concepts by discussing or cooperating in mastering the material [8-10]. With cooperative learning students learn to cooperate, mutual benefit not to compete with each other [11], as in Team Accelerated Instruction learning models which have the characteristics of learning responsibility are in individual students [12, 13], Students must build their own knowledge and not only accept the finished form of the teacher, but the teacher-student communication pattern is negotiation not instruction-imposition [14].

Team Accelerated Instruction is in line with the learning objectives of mathematics in the 2013 curriculum where cooperative learning emphasizes more on the interaction of questions to 
construct knowledge and shape social attitudes or personalities. In other words, cooperative learning can develop to solve problems by constructing knowledge and developing solidity and solidarity through social attitudes or personalities.

The ability to solve problems becomes one of the important things to be instilled in students and must be owned by students in learning mathematics. There are several reasons that problem solving becomes important and becomes one of one's basic abilities in solving mathematical problems. Including problem solving cannot be separated in everyday life, with the ability to solve problems that can be used to provide solutions or answers to problems faced more analytically so that someone can be a problem solver. In other words, if students are trained to solve problems, then students will be able to make decisions, because students have become skilled about how to collect relevant information, analyze information, and realize the need to re-examine the results they have obtained [15].

Evaluation instruments for students have so far been in the form of multiple choices, while questions in the form of descriptions such as story problems are only used during daily tests [16], this makes one of the factors of students' ability to solve mathematical problems still not optimal. The results showed that the ability to solve mathematical problems for students in Indonesia was still low [17-20]. This has led to the need for an Mathematics learning innovation including using Team Accelerated instruction so that the ability to solve mathematical problems is better. In this regard, the purpose of this research is to construct Team Accelerated instruction using mathematical comic to improve mathematical problem solving skills. As is generally known that the ability to solve mathematical problems is one of the abilities that must be possessed by each student in accordance with the objectives of learning Mathematics in Indonesia and also contained in the principles and standards of school mathematics [21].

\section{Method}

This study was a preliminary research and did not intend to make a teaching material or model of learning, but only did a conceptual approach prior to a research development. So, the main method carried out was to compare the various literature related to problem-solving ability and associate to team accelerated instruction models.

\section{Results and Discussion}

\subsection{Team Accelerated Instruction}

Studying mathematics, many mathematical concepts derived from previous concepts [22], mathematics material is much related to abstract ideas that are hierarchically arranged and deductive reasoning [23]. So that the mathematical concepts at the previous level are closely related to understanding the mathematical concepts at the next level. The impact of studying mathematics has consequences on the learning and learning processes that require more serious and profound thinking in learning mathematics. If the initial concept is not mastered, then when studying material that requires previous concepts it will be difficult or impossible to understand the next material. For example, a student who cannot reduce or multiply operations is unable to understand a decimal system. With this Team Accelerated Instruction, students can learn at their own level. If they lack the prerequisite concept, students can explore previous concepts. 
Team Accelerated Instruction has many dynamics compared to STAD or Teams-GamesTournament, which only looks at motivational aspects [22]. Team members on Team Accelerated Instruction learning can learn about different material. Although the emphasis on Team Accelerated Instruction learning model remains in the solidarity of students in the group that can be seen from the conditions of helping each other, working together to answer the problem in the answer sheet and discuss it if there are problems $[8,24]$, but the element of individualization can still be seen through final test or evaluation.

The purpose of the Team Accelerated Instruction is to adapt teaching to individual differences related to students' initial abilities and student achievement [8]. Similar to other cooperative learning, including the Investigation Group with a team equipped with the ability to practice more specific questions then presented together with the group, Jigsaw with 5 basic rules namely reading, discussion, team reports, tests, team recognition [25]. In Team Accelerated Instruction students are grouped into a team consisting of $4-5$ heterogeneous members [8], which distinguishes TAI learning from other cooperative learning is that group rewards are based on how fast each student advances to understand the material through a test held individually. The differences in learning models between Student Team Achievement and Division, and Team Accelerated Instruction include (1) in Student Team Achievement and Division focusing on evaluation in the form of quizzes but in Team Accelerated Instruction using evaluation in the form of exercises, (2) students are responsible for the results of the exercise, because students themselves examine the results of the evaluation on group, (3) teachers can teach small groups from various groups to present the material $[8,14,22,24]$. The striking difference between Team Games Tournament, STAD and Team Accelerated Instruction is the strategy used, in Team Accelerated Instruction is used only for mathematics, especially in algebraic material, is used in grades three to six, the placement of students in the group is used an pre-test, students are allowed to studying different parts, while in Student Team Achievement and Division and Team Games Tournament it is generally used in mathematical, language, and mechanical calculations [26].

Team Accelerated Instruction is a cooperative learning model, so the syntax used in Team Accelerated Instruction learning refers to the syntax of cooperative learning models. The syntax of cooperative learning model is (1) is to convey goals and motivate students, (2) present information, (3) organize students into cooperative groups, (4) guide working and learning groups, (5) evaluation, and (6) provide award [14, 23, 27].

In addition, the components in Team Accelerated Instruction include teams, placement tests, creative students, team studies, team scores and team recognition, teaching groups and fact tests [24]). Teams, namely the formation of heterogeneous groups consisting of 4 to 5 students. Placement Test, which is giving pre-tests to students or seeing the average daily value of students so that the teacher knows the weaknesses of students in certain fields. Student Creative, explores the material that will be studied individually. Team Study, namely the stages of learning actions that must be carried out by the group and the teacher provides individual assistance to students in need. Scores and Team Recognition Team, which is giving scores on the results of group work and giving awards to groups that succeed in learning and obtain the highest score. Teaching Group, namely the explanation by the teacher about the material that has been discussed. Fact Test, which is the implementation of small tests based on facts obtained by students.

\subsection{Media's}

Media is a tool that serves to convey learning messages [28, 29], so that learning processes that use media become more effective [30-33]. This message is conveyed by the teacher, accepted by students to stimulate the mind, feelings, attention or will of students so that it will 
encourage the learning process. The message or information carried by the learning media can be in the form of messages prepared to meet learning needs and students' abilities so that students can actively participate in the learning process.

Because learning media is a communication tool to convey a message to learners to stimulate learners to learn in order to achieve learning goals, then choosing the media needs to consider the learning objectives to be delivered, adjusted to the level of development of students, the media must be adapted to the ability of the teacher, and the media must adapted to the situation and condition or at the right time, place and situation [29], besides the selection of media must also pay attention to the characteristics of the material that will be given to students, the characteristics of students or individual differences in students, and learning support facilities.

In using the learning model, the teacher must choose learning media that are tailored to the characteristics of students or material that will be given to students [34], needs such as ability, the skills and attitudes of students that we want to be mastered by students [35]. By using learning media that is adapted to the characteristics of students or expected student learning outcomes to be maximized.

In order for effective mathematics learning, learning is needed with good and careful planning. One of the things that must be carefully planned in addition to the use of models, strategies and approaches used by learning is learning tools such as syllabi, lesson plans, learning media and learning resources, assessment tools, and learning scenarios. In order to utilize learning media well and effectively it is necessary to pay attention to several aspects such as Analyze Learner Characteristics, State Objectives, Select and Modify or Design Materials, utilize materials, require learner response, and evaluate [29].

The use of media in the teaching and learning process is very important. Some criteria in selecting material to achieve effective results include (1). Interesting, meaning that the media used must be attractive to students, (2). Motivate, meaning that the media used can motivate students to read, (3). Relevant/appropriate, meaning that the media used must be relevant or in accordance with the topics discussed and in accordance with the age of students [36]. In addition, so that the media used appropriately and effectively in learning can consider aspects of visible, interesting, simple, useful, accurate, legitimate, and structured [29]. Although in utilizing learning media it is necessary to realize that (1) there is no single media that is best for all learning objectives, (2) media is an integral part of the learning process, (3) the selection of media should be objective meaning based on learning objectives, the use of some the media will at the same time confuse students, and (4) the goodness and shortcomings of the media do not depend only on their concrete and abstractness, but by using learning media, messages in learning can be easily accepted by students so learning becomes more effective.

\subsection{Implementation Team Accelerated Instruction with Media's To Improve Mathematical Problem Solving Skill}

Problems in mathematics are usually in the form of questions or math questions that must be answered or done by students. Problems can be presented in the form of non-routine questions in the form of story problems, depictions of phenomena or events, illustration of drawings or puzzles and contain mathematical concepts so that the problem is called a mathematical problem [37, 38], mathematical problems are mathematical problems, especially if associated with calculations and efficiency in everyday life [39]. Problems can be presented in the form of non-routine questions in the form of story problems, depictions of phenomena or events, drawing illustrations or puzzles, if the problem contains mathematical concepts, the problem is called a mathematical problem $[37,38]$. Providing non-routine questions to students means training them to apply various mathematical concepts in new situations so that in the end 
they are able to use various scientific concepts they have learned to solve problems in everyday life. Non-routine questions can be used as problem solving problems because they use various concepts, principles, and mathematical skills that have been or are being studied [40], but routine questions can also be a problem for students if students do not have certain rules that can be used to overcome the current situation gap with the objectives to be achieved even though routine questions have been given to students.

Problems in mathematics are divided into two, that is problem to find, this question is a matter of determining or getting certain values that are not known in the problem and meeting certain conditions or conditions, and (2) problem to prove, This type of problem is to determine whether a statement or procedure is true or incorrect [41]. Example of problem to find is " 1234

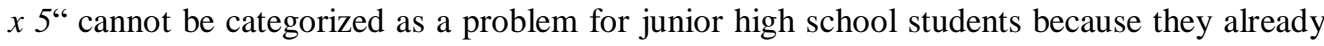
know the procedure to solve the problem at the previous level, but the problem is kind of proving like "prove that $a^{9}-a$ divided 6 , for each integer a" can be a problem or not depends on every student who faces it. For student A, the problem can be a problem because student A does not yet have an idea to solve a mathematical problem or question faced, unlike student B who has an idea to solve the problem. Even though student A and student B are in the same condition and time.

School mathematics problems are generally divided into two, namely routine and nonroutine. Routine questions are ordinary practice questions that include the application of a mathematical procedure that is the same or similar to the new thing learned and can be solved by procedures learned in class, while non-routine or non-routine questions are questions that to solve it further thought is needed because of the procedure not as clear or not as the procedures learned in class [40, 42]. It's not always a matter of routine questions not a problem for students. Routine questions can be a problem if students experience difficulties in completing them. This is because students have the ability to understand problems with different levels of difficulty. This level of difficulty is different which causes that a math question or question for each student will be a problem or not depends on each individual or student itself [43].

The low student achievement can be caused by the ability of students to solve mathematical problems inadequately, this can be shown that students to solve mathematical problems that are irregular and inconsistent [44], Students' creative thinking ability is low [45, 46]. Irregularities in solving problems can be seen that students do not write down what is known and what is asked of the problem, cannot plan to solve the problem and do not re-examine the stages [47]. Though problem solving ability is one of the basic abilities that must be possessed by every student, so that students are able to formulate concepts, develop their ideas, and become problem solvers in everyday life.

Related to problem solving abilities that are still not optimal, at least it takes a learning model that can improve problem-solving skills. Team Accelerated Instruction is a learning model that arises as a result of understanding constructivism, where knowledge is constructed by students by discussing and working together in mastering the material given by the teacher [8-10]. Team Accelerated Instruction has a working pattern compared to competition patterns. Positive characteristics that emerge from the pattern of cooperation include highlighting effective communication, mutual respect, mutual assistance, division of labor and orientation on clear tasks, orderly discussion, willingness to improve the ability of others, deliberation for consensus and high solidarity.

In Team Accelerated Instruction, if students want their team to succeed then group members must work hard, help each other to understand the material or problems [22]. Group members can learn about different material, members in one group help each other, work together to answer the problem on the answer sheet and discuss it if there are problems, the final test is done 
individually, students are not allowed to help each other and the value obtained is considered by students, every week, teachers' pay attention to the amount of material that has been completed by all team members and reward teams that achieve the highest grades [24].

The ability to solve problems in students in groups can be seen in the fourth phase that is guiding the group to work and study. In this phase, students can become problem solvers in every problem faced. Even if group members belong to the creative category in solving problems, it can be possible for each problem to be encountered in a different way or process for each group member. So that each group member can do re-checking or look back at the answers proposed by each group member so that all possible answers obtained logically and sensibly are used to solve problems.

While the ability to solve individual problems can be seen in the evaluation phase. Evaluation is done to pay attention to the amount of material that has been mastered by students. In order to improve problem-solving skills, evaluation questions are arranged in the form of a description question instead of multiple choice questions. The problem in the form of multiple choice causes the teacher difficult to see the process of students in solving problems, different if using a description problem that prioritizes the problem-solving process than the result.

The results of research conducted on eighth grade students in six junior high schools in the city of Yogyakarta showed that the ability to solve mathematical problems that use the TAI learning model is better when compared to direct learning models, so that the TAI learning model is more effective than using direct learning models [23, 27, 48]. Based on this, it is suspected that learning to use the Team Accelerated Instruction can improve students' ability to solve mathematical problems.

By referring to the syntax of cooperative learning, namely (1) conveying goals and motivating students, (2) presenting information, (3) organizing students into cooperative groups, (4) guiding working and learning groups, (5) evaluating and (6) giving awards [8, 24], as well as the components of Team Accelerated Instruction learning, namely teams, placement test, student creative, team study, team score and team recognition, teaching group and fact test [8, 48], then the steps of Team Accelerated learning Instruction is (1) conveying learning objectives to be achieved at each meeting, (2) holding placement tests or placement tests to place students into groups, (3) grouping students into small groups, (4) learning in groups or group discussions, (5) individual tests, and (6) group awards.

To support learning activities in the fourth phase, teachers can use teaching materials and learning media to facilitate the learning process of mathematics by using Team Accelerated Instruction learning models. In mathematics material that has abstract characteristics causes students to be difficult in understanding mathematical concepts. This needs to be considered by the teacher, especially for junior high school teachers in implementing mathematics learning. Because using the right media makes math learning more effective.

\section{Conclusion}

Based on the discussion carried out, it can be concluded that Team Accelerated Instruction can improve mathematical problem solving skills. By using visual learning media in Team Accelerated Instruction learning, students are expected to understand the concept of mathematics which has abstract properties. Because learning media can function as a tool to 
conclude abstract material. Related to this, it is necessary to design visual learning media for Team Accelerated Instruction to make learning more effective.

\section{References}

[1] I. W. Dasna, "Hakikat Pembelajaran Inovatif dan Interaktif," Tangerang Selatan: Universitas Terbuka, 2015, pp. 1-61.

[2] D. P. Kartiwi, "Pengaruh Pembelajaran Berbasis Masalah ditinjau dari Bakat Numerik dan Kecemasan Siswa terhadap Prestasi Belajar Matematika Siswa Kelas X SMA Negeri 1 Kuta," J. Ilm. Pendidik. dan Pembelajaran, vol. 7, no. 2, pp. 1-11, 2011.

[3] Mundilarto, "Pendekatan Kontekstual Dalam Pembelajaran Sains," Cakrawala Pe2ndidikan, vol. 23, no. 1, pp. 63-80, 2004.

[4] Chu Chih Liu and I. Ju (Crissa) Chen, "Evolution Of Constructivism," Contemp. Issues Educ. Res., vol. 3, no. 4, pp. 63-66, 2010.

[5] K. C. Powel and C. J. Kalina, "Cognitive And Social Constructivism: Developing Tools For An Effective Classroom," Education, vol. 130, no. 2, 2018.

[6] M. J. Prince and R. M. Felder, "Inductive Teaching and Learning Methods: Definitions, Comparisons, and Research Bases," J. Eng. Educ., vol. 95, no. 2, pp. 123-138, 2006.

[7] N. Vos, H. Van Der Meijden, and E. Denessen, "Effects of Constructing Versus Playing an Educational Game on Student Motivation and Deep Learning Strategy Use," Comput. Educ., vol. 56, no. 1, pp. 127-137, 2011.

[8] R. E. Slavin, Cooperative Learning: Theory, Research and Practice. New Jersey: Prentice Hall, 1995.

[9] P. D. Eggen and D. P. Kauchak, Learning and teaching. New York: Allyn \& Bacon, 1993.

[10] P. D. Eggen and D. P. Kauchak, Strategies for teacher teaching content and thinking skills. Boston: Allyn and Bacon. Boston: Allyn \& Bacon, 1996.

[11] D. Boud, R. Cohen, and J. Sampson, Peer Learninq in Higher Education: Learning From \& With Each Other. New York: Routledge, 2013.

[12] E. Kyndt, E. Raes, B. Lismont, F. Timmers, E. Cascallar, and F. Dochy, "A metaanalysis of the effects of face-to-face cooperative learning. Do recent studies falsify or verify earlier findings?," Educ. Res. Rev., vol. 10, pp. 133-149, 2013.

[13] J. M. Dotson, "Cooperative Learning Structures Can Increase Student Achievement," Kagan Online Mag., 2001.

[14] A. S. A. S. Purnami, S. A. S. A. Widodo, and R. C. I. R. C. I. Prahmana, "The Effect of Team Accelerated Instruction on Students' Mathematics Achievement And Learning Motivation," J. Phys. Conf. Ser., vol. 948, no. 1, pp. 1-5, 2018.

[15] D. B. Widjajanti, "Kemampuan Pemecahan Masalah Matematis Mahasiswa Calon Guru Matematika: Apa Dan Bagaimana Mengembangkannya," in Prosiding Seminar Nasional Matematika dan Pendidikan Matematika, 2009, pp. 1-11.

[16] S. A. Widodo and A. . Sujadi, "Analisis Kesalahan Mahasiswa Dalam Memecahkan Masalah Trigonometri," Sosiohumaniora J. Ilmu Sos. dan Hum., vol. 1, no. 1, pp. 5163, 2015.

[17] R. Rosnawati, "Kemampuan penalaran matematika siswa SMP Indonesia pada TIMSS 2011," in Prosiding Seminar Nasional Penelitian, Pendidikan dan Penerapan MIPA, 2013. 
[18] A. Istiandaru, N. Syakrina, F. Setyawan, R. Charitas, I. Prahmana, A. Sofyan, and E. Hidayat, "How Students Solves PISA Tasks : An Overview of Students 'Mathematical Literacy," vol. 2, no. 2, pp. 129-138, 2018.

[19] R. Novita, Zulkardi, and Y. Hartono, "Exploring Primary Student's Problem-Solving Ability by Doing Tasks Like PISA's Question,” J. Math. Educ., vol. 3, no. 2, pp. 133 $150,2012$.

[20] K. Stacey, "The PISA View of Mathematical Literacy in Indonesia," J. Math. Educ., vol. 2, no. 2, pp. 95-126, 2011.

[21] NCTM, Principles and Standards For School Mathematics. Virginia: NCTM, 2000.

[22] Z. Jianhua and K. Akahori, "Web-Based Collaborative Learning Methods and Strategies in Higher Education," in Information Technology Based Higher Education and Training (ITHET), 2001.

[23] S. A. Widodo, "Keefektivan Team Accelerated Instruction Terhadap Kemampuan Pemecahan Masalah dan Prestasi Belajar Matematika Siswa Kelas VIII," J. Mat. Kreat., vol. 6, no. 2, pp. 127-134, 2015.

[24] R. E. Slavin, Student Team Learning: A Practical Guide to Cooperative Learning. Washington: NEA Publ, 1991.

[25] G. Ghaith, "Effects of the Learning Together Model of Cooperative Learning on English as a Foreign Language Reading Achievement , Academic Self- Esteem , and Feelings of School Alienation," Biling. Res. J., vol. 27, no. 3, pp. 451-474, 2003.

[26] A. Robinson, Cooperative Learning And The Academically Talented Student. Storrs: National Research Center on the Gifted and Talented, 1991.

[27] A. S. Purnami, S. A. Widodo, and R. C. I. Prahmana, "The Effect Of Team Accelerated Instruction On Students' Mathematics Achievement And Learning Motivation,” in Journal of Physics: Conference Series, 2018, vol. 948, no. 1.

[28] E. Mediawati, "Pembelajaran Akuntansi Keuangan Melalui Media Komik Untuk Meningkatkan Prestasi Mahasiswa," J. Penelit. Pendidik., vol. 12, no. 1, pp. 61-68, 2011.

[29] S. A. Widodo, "Selection of Learning Media Mathematics for Junior School Students," Turkish Online J. Educ. Technol., vol. 17, no. 1, pp. 154-160, 2018.

[30] M. Bulut, H. Ü. Akçakın, and G. Kaya, "The Effects of GeoGebra on Third Grade Primary Students' Academic Achievement in Fractions," Int. Soc. Educ. Res., vol. 11, no. 2, pp. 347-355, 2016.

[31] A. K. Ismail and P. Hendikawati, "Efektivitas Model Pembelajaran Teams Group Tournament (TGT) Dengan Menggunakan Media '3 In 1' Dalam Pembelajaran Matematika," UNNES J. Math. Educ., vol. 2, no. 2, 2013.

[32] A. A. Nugroho, "Pengembangan Perangkat Pembelajaran Matematika Berbasis Smart Dengan Strategi Tai Pada Materi Segitiga Kelas Vii," Aksioma, no. Vol 2, No 2/September (2011): AKSIOMA, 2011.

[33] A. Muhson, "Pengembangan Media Pembelajaran Berbasis Teknologi Informasi," J. Pendidik. Akunt. Indones., vol. VIII, no. 2, pp. 1-10, 2010.

[34] R. A. Reiser and R. M. Gagne, "Characteristics of Media Selection Models," Rev. Educ. Res., vol. 52, no. 4, pp. 499-512, 1982.

[35] T. Nurseto, "Membuat Media Pembelajaran yang Menarik," Ekon. Pendidik., vol. 8, pp. 19-35, 2011.

[36] M. Johana, "Komik Sebagai Media Pengajaran Bahasa Yang Komunikatif Bagi Siswa Smp," Lembaran Ilmu Kependidikan Jilid, vol. 36, no. 1, pp. 28-34, 2007.

[37] D. A. M. Lidinillah, "Heuristik Dalam Pemecahan Masalah Matematika Dan 
Pembelajarannya Di Sekolah Dasar,” J. Elektron. Univ. Pendidik. Indones., pp. 1-11, 2011.

[38] D. A. M. Lidinillah, "Strategi Pembelajaran Pemecahan Masalah di Sekolah Dasar,” J. Pendidik. Dasar, pp. 1-10, 2008.

[39] B. P. Darminto, "Meningkatkan Kemampuan Pemecahan Masalah Matematis Improving The Ability Of Students ' Mathematical Problem Solving," J. Pendidik. Mat. dan Sains, vol. 1, no. 2, pp. 101-107, 2013.

[40] Nyimas Aisyah, "Pendekatan Pemecahan Masalah Matematika," in Pembelajaran Matematika Sekolah Dasar, Yogyakarta: UNY, 2008, pp. 1-34.

[41] G. Polya, How Solve It: A new Aspect of Mathematical Method. New Jersey: Princeton University Press, 1973.

[42] Wahyudi and I. Budiyono, Pemecahan Masalah Matematika. Salatiga: Widya Sari Press, 2011.

[43] I. Rizkianto, "Norma Sosiomatematik Dalam Kelas Matematika," in Prosiding Seminar Nasional Matematika dan Pendidikan Matematika, 2013, no. November, pp. 978-979.

[44] Pardimin and S. A. Widodo, "Increasing Skills of Student in Junior High School to Problem Solving in Geometry with Guided," J. Educ. Learn., vol. 10, no. 4, pp. 390395, 2016.

[45] K. S. Perbowo and T. R. Pradipta, "Pemetaan Kemampuan Pembuktian Matematis Sebagai Prasyarat Mata Kuliah Analisis Riil Mahasiswa Pendidikan Matematika," Kalamatika, vol. 2, no. 1, pp. 81-90, 2017.

[46] K. S. Perbowo and R. Anjarwati, "Analysis of Students' Learning Obstacles on Learning Invers Function Material,” Infin. J., vol. 6, no. 2, p. 169, 2017.

[47] S. A. Widodo, "Development of Teaching Materials Algebraic Equation To Improve Problem Solving," Infin. J., vol. 6, no. 1, p. 59, 2017.

[48] S. A. Widodo, A. S. Purnami, and R. C. I. Prahmana, "Team Accelerated Instruction, Initials, And Problem-Solves Ability In Junior High School," Int. J. Emerg. Math. Educ., vol. 1, no. 2, pp. 193-204, 2017. 